\title{
Editorial
}

\section{SBTMO: Presente e futuro. Ainda há muito a fazer...}

\section{Daniel G. Tabak}

No período de 4 a 7 de agosto próximo estaremos realizando o $6^{\circ}$ Congresso da Sociedade Brasileira de Transplante de Medula Óssea (SBTMO). Este evento marca várias etapas da evolução da nossa Sociedade e reflete a necessidade permanente de mudanças.

Ao longo dos últimos quatro anos, esta diretoria procurou implementar várias decisões críticas consideradas nas nossas assembléias anuais. Entretanto, ainda há muito o que fazer.

A realização deste evento, este ano no Rio de Janeiro, cria novas possibilidades e desafios para as próximas diretorias. A qualidade dos congressos anteriores realizados em Curitiba determina que estejamos atentos para que o mesmo padrão seja mantido. Esta foi a nossa maior prioridade na escolha dos palestrantes e dos temas a serem debatidos.

Em primeiro lugar, trata-se do Congresso da SBTMO e neste sentido é necessário que toda a Sociedade esteja engajada no empreendimento. Membros da Sociedade foram consultados e manifestaram o seu interesse em determinados assuntos. A comissão científica, constituída por companheiros de várias procedências, teve um papel fundamental na definição dos temas para os debates. Procuramos estimular o pesquisador nacional instituindo o Prêmio Mary Evelyn Flowers que será outorgado ao melhor trabalho apresentado. Modificamos o formato das apresentações introduzindo sessões interativas, com o objetivo de permitir uma maior discussão da platéia com os palestrantes. Apesar da ênfase no transplante hematopoético, foi preservada a abordagem direcionada a hemopatias malignas, com o objetivo de oferecer à comunidade hematológica o verdadeiro significado do transplante na prática clínica diária. Procuramos ainda valorizar o trabalho do pesquisador nacional através da sua participação nas mesas redondas e da apresentação do seu trabalho junto aos expositores estrangeiros.

Temos muito do que nos orgulhar: é inegável o crescimento da comunidade brasileira envolvida com o transplante hematopoético. Esta comunidade é constituída não apenas por médicos e reflete o aspecto multidisciplinar da especialidade. Somos também enfermeiros, imunogeneticistas, biólogos, técnicos, pesquisadores. Ao integrarmos os encontros de enfermagem e o de imunogenética, garantimos a expansão do conhecimento em todas as áreas e uma maior participação dos congressistas.

O congresso marca ainda o final de um ciclo. Apesar de várias realizações temos também uma certeza: ainda há muito o que fazer.

Conseguimos, entretanto, registrar alguns avanços que precisam ser mencionados. Observamos um número crescente de associados e de centros de Transplantes em todo o Brasil. A Sociedade Brasileira de Transplante de Medula Óssea (SBTMO) hoje está diretamente associada à Sociedade Brasileira de Hematologia e Hemoterapia (SBHH) e a Revista Brasileira de Hematologia e Hemoterapia é também o nosso órgão oficial de divulgação científica. Encontra-se em preparação o

Presidente da Sociedade Brasileira de Transplante de Medula Óssea

\section{Correspondência para:}

Praça Cruz Vermelha, 23. CEP 20230-130. Rio de Janeiro. RJ

E-mail: dantabak@unisys.com.br 
primeiro texto em língua portuguesa que aborda o transplante de medula óssea nos seus vários aspectos, inclusive com a participação de expoentes da comunidade internacional. Os recursos advindos da publicação serão integralmente revertidos para a Sociedade.

Aprendemos muito nestes quatros anos. Fica claro que a Sociedade precisa ter voz própria, manter sua identidade e defender os nossos princípios. Somos jovens em desenvolvimento e não temos dúvidas que as dificuldades do presente frutificarão em novas realizações para as próximas diretorias e que, todos juntos, caminharemos para o fortalecimento contínuo da SBTMO.

Recebido -14/06/2002

Aceito - 15/06/2002 